\title{
Genetic Markers from Biomphalaria tenagophila (Gastropoda: Pulmonata: Planorbidae) Obtained by the Double Stringency Polymerase Chain Reaction Technique
}

\author{
Roseli Tuan+, Paula Cristina Bortolato \\ Laboratório de Malacologia, Superintendência de Controle de Endemias, Rua Paula Souza 166, \\ 01027-000 São Paulo, SP, Brasil
}

Biomphalaria tenagophila, one of the intermediate hosts of the trematoda Schistosoma mansoni, is a simultaneous hermafrodite snail species. In order to analyse the genetic structure of these populations, we performed a double-stringency PCR technique to obtain genetic markers with microsatellites and arbitrary primers in a single reaction.

Key words: Biomphalaria - DNA polymorphism - PCR

Biomphalaria are simultaneous hermaphrodite freshwater snails, which can breed mainly by cross (Paraense 1955) but also by self-fertilization (Tuan $\&$ Simões 1998). Analysis of the effects of reproduction in freshwater snails using genetic markers such as isozymes (Bandoni et al. 1995) shows heterozygote deficiencies indicating that selfing could be a regular mating strategy creating complex patterns of population structure exhibiting genetic differences that can cause differences in susceptibility to Schistosoma mansoni (Hofman et al. 1998).

Molecular markers are in large use for freshwater snails diagnosis, mainly PCR based protocols which show a great power for quick and simple characterization of genetic variation within and among populations (Avise 1994). DS-PCR described here combines the specificity of microsatellites and the simplicity of amplification of RAPDS markers in a double stringency condition leading to the amplification of selective population of DNA. The technique produced genetically informative co-dominant markers in Drosophila mercatorum (Matioli \& Brito 1995).

We applied DS-PCR to laboratory strains $B$. tenagophila from Tremembé, São José dos Campos and Bananal, all from endemic areas in São Paulo, SP; and a strain from Taim, RS, a non-endemic area. In order to observe intra-population

Financial support: Fapesp (Proc. 99/0091-7)

${ }^{+}$Corresponding author. Fax: +55-11-229.8292. E-mail: tuan@sucen.sp.gov.br

Received 13 November 2000

Accepted 3 January 2001 variation we used 12 B. tenagophila snails collected from rice paddies at Tremembé, SP, a site with a long history of $S$. mansoni transmission (Silva 1992). The hepatopancreas-ovotestis complex were extracted from snails previously identified by morphological reproductive traits (according to Paraense 1975), and free from S. mansoni infection. We used a standard phenol-chloroform protocol for DNA extraction (Sambrock et al. 1989) which produced a clear pattern of DNA (Fig. 1).

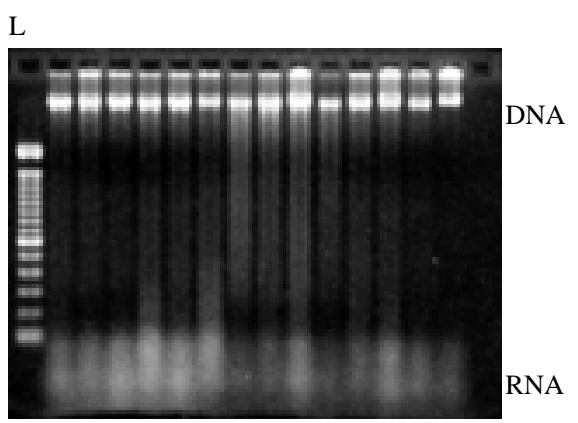

Fig. 1: DNA from Biomphalaria tenagophila $(\mathrm{n}=14)$ shows high molecular weight.

The reactions were done in a $25 \mu \mathrm{l}$ volume containing: $2.5 \mu \mathrm{l}$ buffer, $1.25 \mu \mathrm{l} \mathrm{MgCl} 250 \mathrm{mM}, 5 \mu \mathrm{l}$ DNTPs mix, $0.25 \mu l$ of microsatellites primer, $1 \mu \mathrm{l}$ of RAPD primer, $0.25 \mu \mathrm{l}$ of Taq DNA polymerase and $2 \mu \mathrm{l}$ of extracted DNA, and $12.75 \mu \mathrm{l}$ of distilled water. The microsatellites and RAPD combinations used were $4 \mathrm{C}\left[(\mathrm{CAG})_{4}\right.$ and GAACGGACTC], 5C [(GAG) $)_{4}$ and GAACGGA CTC], 6C [(AACG) $)_{4}$ and GAACGGACTC], 7C [(ATCG) $)_{4}$ and GAACGGACTC], 10C [(CGGA) ${ }_{4}$ and GAACGGACTC], 14C [(TTTG $)_{4}$ and GAA CGGACTC]. All reactions were performed with a Minicycler Termocycler (MJ Research). 
The temperature profile was the following: a first denaturation step at $94^{\circ} \mathrm{C}$ for $2 \mathrm{~min}+15$ cycles at $94^{\circ} \mathrm{C}$ for $30 \mathrm{~s}-52^{\circ} \mathrm{C}$ for $45 \mathrm{~s}$ and $72^{\circ} \mathrm{C}$ for $60 \mathrm{~s}+$ 25 cycles at $94^{\circ} \mathrm{C}$ for $30 \mathrm{~s}-35^{\circ} \mathrm{C}$ for $45 \mathrm{~s}-$ a ramp of $60 \mathrm{~s}$ to $72^{\circ} \mathrm{C}$ for $60 \mathrm{~s}$. Finally extension at $70^{\circ} \mathrm{C}$ for $10 \mathrm{~min}$. The products were analyzed by agarose gel electrophoresis (1.4\% in TBE buffer) and stained with ethidium bromide $(\mathrm{EtBr})$.

The interpopulational profiles of the six primer combinations show a significant degree of genetic variation, suggesting heterogeneous genetic population patterns (Fig. 2).

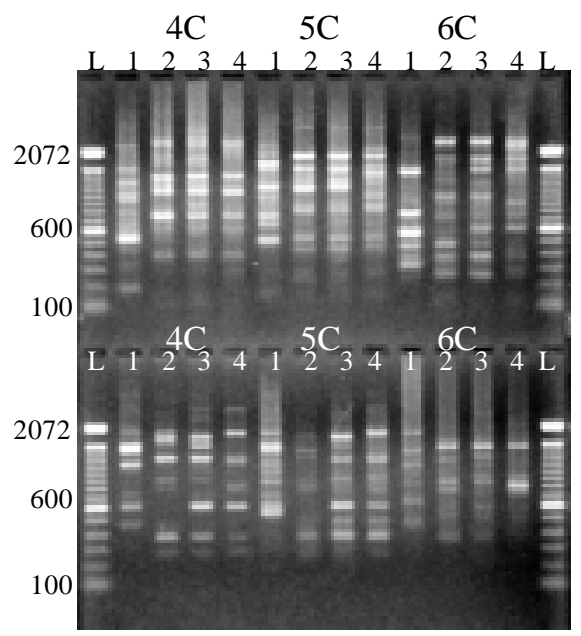

Fig. 2: bands produced with six primers combinations by DSPCR in four Biomphalaria tenagophila population.

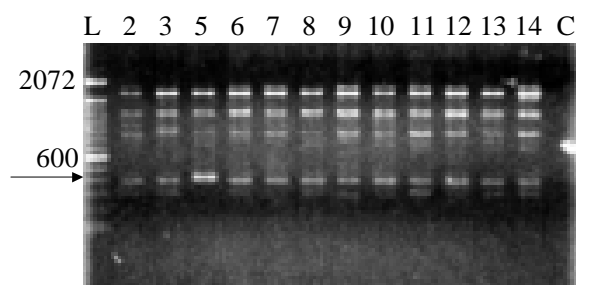

Fig. 3: bands produced by primer 7C (the arrow indicates the polymorphic markers, L indicates the DNA Ladder, the numbers in the left indicate the approximate sizes in $\mathrm{pb}$, and $\mathrm{C}$ indicates control).
At the intrapopulational level DS-PCR generates polymorphisms that can contribute with the comparison of populations derived from different environmental conditions (Fig. 3).

We concluded that DS-PCR is an excellent tool that can be applied to identify genetic polymorphisms within and among hermaphrodite snail populations. DS-PCR employed here is a method which has the large applicability of RAPD but also can generate codominant markers that are more informative for population analyses.

\section{ACKNOWLEDGMENTS}

To Dr Sergio Russo Matioli and Dr Priscila dos Santos for their kind and valuable help.

\section{REFERENCES}

Avise JC 1994. Molecular Markers, Natural History and Evolution, Chapman \& Hall, 511 pp.

Bandoni SM, Mulvey M, Loker ES 1995. Intraspecific and interspecific patterns of allozyme variation among species of Biomphalaria Preston, 1910 (Gastropoda: Planorbidae). Biochem Syst Ecol 23: 593616.

Hoffman JI, Webster JP, Ndanba J, Woolhouse MEJ 1998. Extensive genetic variation revealed in adjacent populations of the schistosome intermediate host Biomphalaria pfeifferi from a single river system. Ann Trop Med Parasitol 92: 693-698.

Matioli SR, Brito RA de 1995. Obtaining genetic markers by using double-stringency PCR with microsatellites and arbitrary primers. Biotechniques 19: 752-758.

Parense WL 1955. Autofecundação e fecundação cruzada em Australorbis glabratus. Mem Inst Oswaldo Cruz 53: 277-284.

Paraense WL 1975. Estado atual da sistemática dos planorbídeos brasileiros. Arq Mus Nac 55: 105-128.

Sambrock J, Fritsch EF, Maniatis T 1989. Molecular Cloning. A Laboratory Manual, 2nd ed., Cold Spring Harbor Laboratory Press.

Silva LJ da 1992. A Esquistossomose Mansônica no Estado de São Paulo: Origens, Distribuição, Epidemiologia e Controle. Thesis, Faculdade de Ciências Médicas, Universidade Estadual de Campinas, Campinas, 140 pp.

Tuan R, Simões LCG 1998. Effect of self-fertilization on Biomphalaria tenagophila (Orbigny, 1835) (Pulmonata: Planorbidae). Gen Mol Biol 21: 477478. 